\title{
Glaciers Retreat and Climate Change Effect During the Last One Century in the Mestiachala River Basin, Caucasus Mountains, Georgia
}

\author{
Levan G. Tielidze, Nino Lomidze, Lasha Asanidze \\ Vakhushti Bagrationi Institute of Geography, Ivane Javakhishvili Tbilisi State Uniersity. Tbilisi, Georgia
}

Email address:

levan.tielidze@tsu.ge (L. G. Tielidze), levani.tielidze@gmail.com (L. G. Tielidze)

\section{To cite this article:}

Levan G. Tielidze, Nino Lomidze, Lasha Asanidze. Glaciers Retreat and Climate Change Effect During the Last One Century in the Mestiachala River Basin, Caucasus Mountains, Georgia. Earth Sciences. Vol. 4, No. 2, 2015, pp. 72-79. doi: 10.11648/j.earth.20150402.12

\begin{abstract}
The dynamics of glaciers of Mestiachala river basin for the last century is revised in the paper. The percentage shrinking of areas of compound valley glaciers with the relation of air temperature is given. The retreat of largest glacier of Georgia Lekhziri and shrinking of its area is revised according to the years. The height gradient and correlation between the air temperature data of the only meteorological station (Mestia) of region and air temperature data of the glacier Chalaati in 2011 is determined. The time series of air temperature for Chalaati glacier in 1906-2011 are restored by the using of transfer function. The surface ablation of Chalaati glacier is also calculated. During the study we used a 1:42 000 scale topographic maps of the 19th century, which were drawn up during the first topographic survey by using the plane-table surveying method. Also, we used the catalog of the glaciers of the southern slope of the Caucasus compiled in 1911 by a well-known researcher of the Caucasus K. Podozerskiy, which is drawn up on the basis of the 19th century maps. In order to identify the area and number of the glaciers of the 60s of the 20th century, we used the work of R. Gobejishvili - the Georgian glaciologist of the 20-21st centuries, composed on the basis of 1:50 000 scale topographic maps of 1960. The data of 2014 have been obtained by the Landsat aerial images of L5 TM (Thematic Mapper) taken in August 2014. In the mentioned study, except of the old topographic maps and aerial images we use the climate information of the Mestia weather station.
\end{abstract}

Keywords: Glaciers Dynamic, Remote Sensing, Glaciers of Georgia-Caucasus Mountains, Lekhziri and Chalaati Glaciers

\section{Introduction}

Glaciers have been one of the main contributors to sea level change during the last century [1]. Also, Glaciers are among the most fascinating elements of nature, an important freshwater resource, they are close to the melting point and react strongly to climate change, glaciers are important indicators of global climate [2]. The combination of the different types of information on glacier length fluctuations across the globe has a large potential for the reconstruction of a worldwide picture of past glacier changes [3]. The rate of glacier retreat is, however, regionally variable and depends on local factors such as mass balance, glacier geometry, debris cover and orientation [4]. The resulting variety in glacier settings strongly complicates general statements about the future evolution of glaciers worldwide. Recent studies based on scaling arguments have attempted to provide a global estimate of the future mass loss of mountain glaciers $[5,6,7,8]$.
Mountain glaciers are widely recognized as excellent indicators of climate change over recent centuries $[9,10,11]$. The major and worldwide retreat of mountain glaciers started at the end of the Little Ace Age (LIA), in approximately the mid-1 $19^{\text {th }}$ century [12].

The spatial distribution of mountain glaciers in the territory of Georgia is stipulated by the peculiarities of atmospheric processes, morphological-morphometric conditions of the relief and their interaction. Main centers of glaciation are related to the elevated Greater Caucasus range and Kazbegi massif. Individual centers can be found in the Greater Caucasus branch ranges [13].

\section{Study Area}

The glacierized area of the Caucasus extends for about $1,000 \mathrm{~km}$ from the northwest to the southeast [14]. The Caucasus Range exerts a moderating influence on the climate of Georgia by protecting it against the penetration of cold air 
masses from the north. Most moisture-bearing weather systems arrive from the west having passed over the Black Sea. Orographic lifting of convergent air masses in western Georgia creates favorable conditions for snowfall at any time of the year in the high mountains. In contrast, a secondary pattern of weather systems originates in drier continental climate to the east of the Caspian Sea. These meteorological conditions give rise to a strong west-east gradient in precipitation, reflected in annual snowfalls of several meters in the western parts of the Caucasus and less than a meter in the east [15].

According to the morphological and morphometric characteristics the Greater Caucasus can be divided into three parts within Georgia - Western, Central and Eastern [13].

Mestiachala River basin is located on the southern slope of the central Caucasus from the Mount Ushba to the Mount Bashili (Fig.1). It is aright tributary of the the Mulkhura River. Its length is 11 kilometers and the area of the basin is $150 \mathrm{~km}^{2}$. Mestiachala River gorge maintains a trough form, while the bottom of the gorge is transformed due to the erosion processes below Mestia to the village of Latali. However, the trace of the ancient glaciation is well preserved on the slope. In the Late Pleistocene the glaciers of the Mulkhura and Mestiachala river gorges were united and with this united tongue they went down to the village of Latali. Chalaati glacier located in this basin comes down to the lowest height among the Caucasus glaciers, to an altitude of 1960 meters and intrudes into the forest zone.

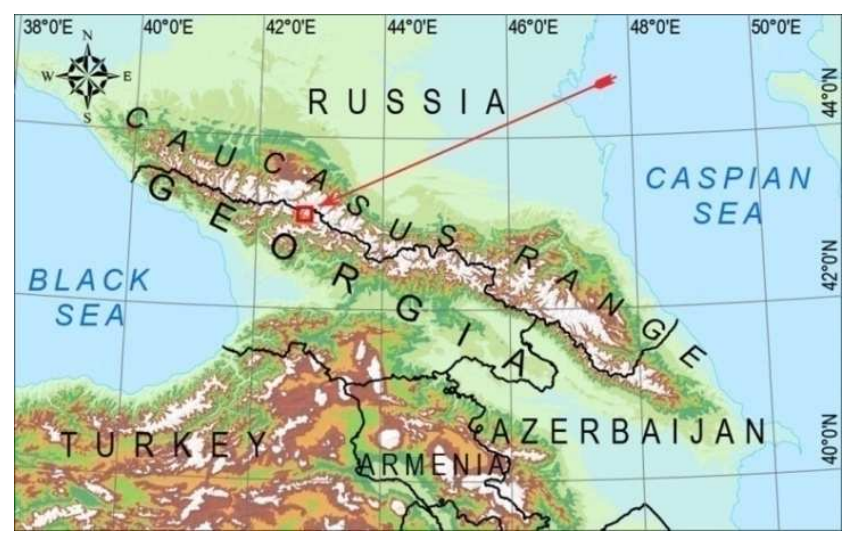

Fig. 1. Location of the Mestiachala River Basin.

In the Mestiachala River basin the leading place by the number occupy the small cirque glaciers (Fig. 2). As for the exposition, the glaciers of the overall southern exposition dominate in the Mestiachala River basin according to the number and area. Their share is $71.4 \%$ in the number and $90.4 \%$ in the area of the glaciers (Fig. 3 ).

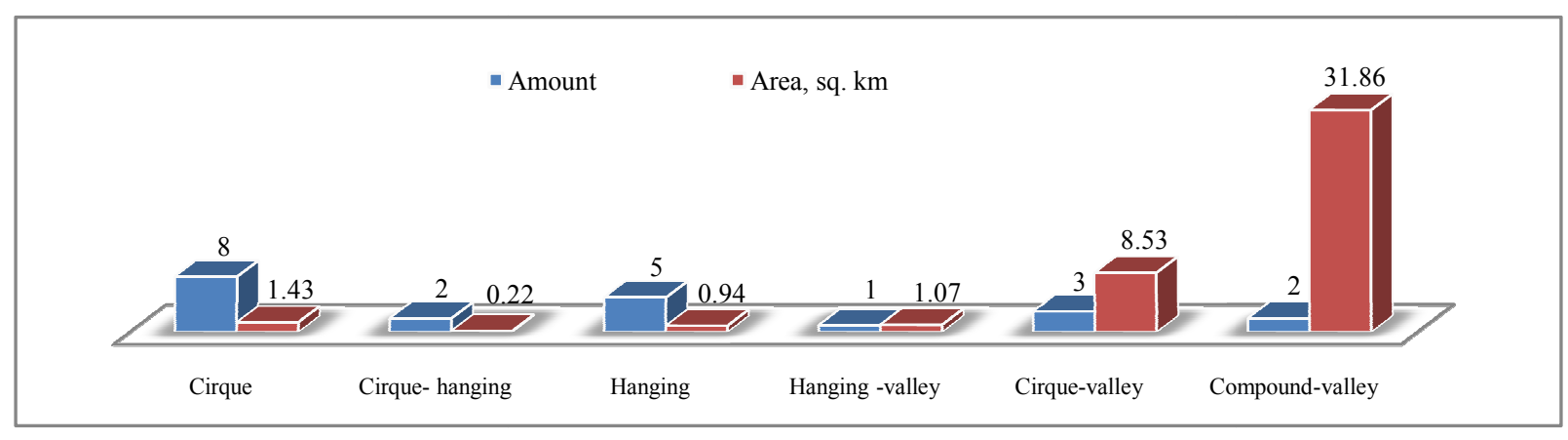

Fig. 2. Distribution of the glaciers in the Mestiachala River basin according to the morphological types.

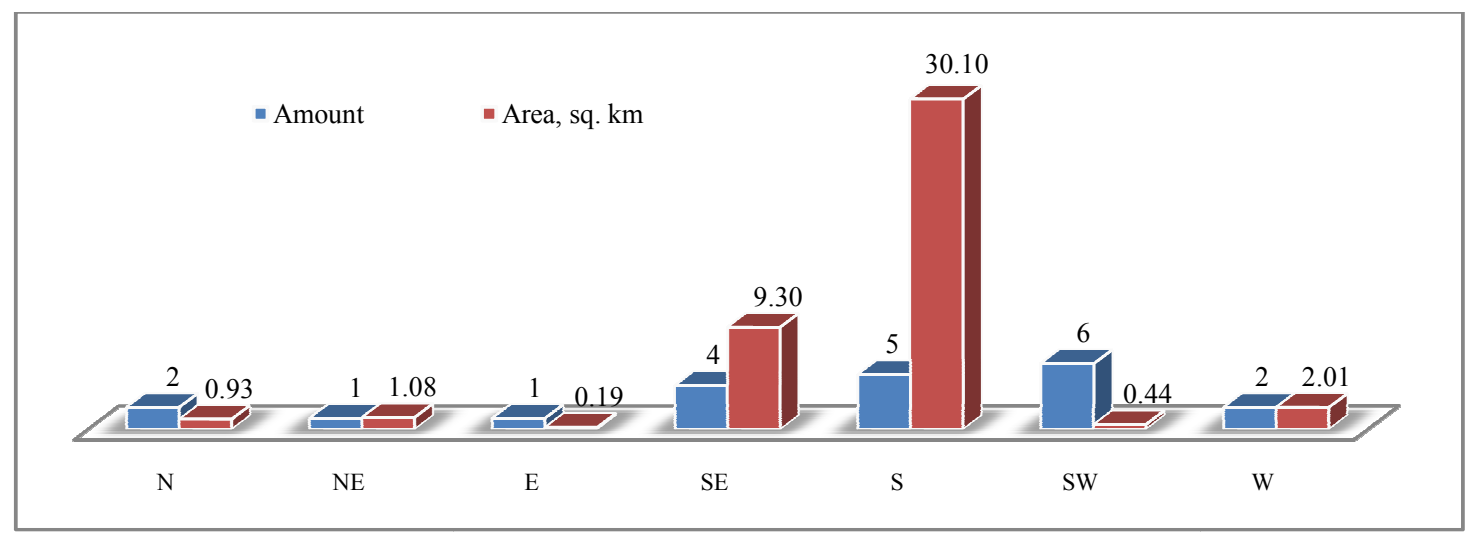

Fig. 3. Distribution of the glaciers in the Mestiachala River basin according to the exposition.

It should be noted that at present the largest glacier ofthe southern slope of the Greater Caucasus is located in this basin, it is a compound-valley glacier of Lekhziri. There is a second compound-valley glacier in this basin - Chalaati.
These two glaciers create main conditions for glaciation (together with the separate Central Lekhziri). Their share in the area of the glaciers of the entire basin is $86.6 \%$. 


\section{Data and Methods}

Maps and the aerial images of different years are needed to describe the dynamics of glaciers. 1:42 000 large scale topographic maps of the Caucasus were compiled by the plain table surveying method in 1880-1890.

In 1911 K. I. Podozerskiy published the first inventory of the Caucasus glaciers, compiling data on the lengths and areas of all of the glaciers [16]. The data by K. Podozerskiy are obtained just from the maps of 1880-1890; detailed analyzes of the data showed that there are many defects in the shape of the glaciers of that time, particularly the inaccessible firn valleys of the valley glaciers are depicted incorrectly. Naturally, this fact will cause a slight error in the identification of precise areas of the glaciers of that time, but in reality there exist no other data about the mentioned period and these maps are the most reliable source for us.

The old topographic maps were replaced with the new ones in 1960, when during the period of the former Soviet Union the 1:50 000 scale maps were published with the depiction of quite precise contours of the glaciers of the Caucasus. R. Gobejishvili gave us new statistical information about the glaciers of Georgia [17].

In order to identify the number and area of the modern glaciers we use remote sensing method, In particular Landsat 5 Thematic Mapper (TM) satellite Imagery. TM images have a pixel resolution of $28.5 \mathrm{~m}$ for the visible bands used in this study. Generating a time series requires all images to be accurately co-registered to one another. To facilitate mapping the glacier boundaries, we produced a color-composite scene for each acquisition date, using bands 7 (short-wave infrared), 4 (near infrared) and 2 (blue). Each glacier boundary was manually digitized by a single operator. Manual digitizing by an experienced analyst is usually more accurate than automated methods for glaciers with heavy debris cover [18], such as Chalaati Glacier. Combining the images with the baseline topographic maps allows us to estimate the variability of Mestiachala River basin glaciers over two epochs corresponding to 1911-1960 and 1961-2014.

A field campaign was carried out on Chalaati Glacier during a three month period in 2011 (June-August). Observations include hourly air temperature measurements at an elevation of 2140 meters above sea level using a and Campbell CR21 Data Logger. We also made weekly observations of ablation at several elevations, by measuring the exposed heights of stakes drilled into the glacier surface. Glacier melting was measured on the various elevations.

During a brief follow-up field visit on August 2014, we surveyed the terminus using global positioning system (GPS) methods.

\section{Results}

By 1911 there were 10 glaciers in the Mestiachala River basin with the total area of $55.2 \mathrm{~km}^{2}$ [16]. By the data of 1960 there were 25 glaciers with the area of $57.5 \mathrm{~km}^{2}$ [17]. If the increase in number of the glaciers were in harmony with the common regularities, the same can't be said for the area, because as in the other basins, the area must also be reduced. The reason is easy to explain. Old maps show the firn valleys of the Chalaati and Lekhziri glaciers very inaccurately, which led to increase in the area against the general background of the retreat of glaciers in the years of 1911-1960. By the data of 2014 there are 21 glaciers in the basin with the total area of $44.1 \mathrm{~km}^{2}$ [13].

As it was mentioned above, Lekhziri - the largest glacier of Georgia is located in the Mestiachala River basin, as well as the compound-valley type of glacier of Chalaati and the largest cirque type of glacier of Georgia - central (northern) Lekhziri. And these three large glaciers create the main background for contemporary glaciation in this basin.

The Lekhziri glacieris a compound-valley glacier and consists of two main flows. According to the data of 1911 the glacier area was $40.8 \mathrm{~km}^{2}$ and its tongue flowed down at a height of 1730 meters above sea level (Fig. 4a). For that time Lekhziri was the third largest glacier in Georgia in size after Tviberi $\left(49.0 \mathrm{~km}^{2}\right)$ and Tsaneri (together with Nageba-48.9 $\mathrm{km}^{2}$ ). In the years of 1911-1960 the glacier area was reduced to $36.0 \mathrm{~km}^{2}$. The area reduction was mainly caused by the shortening of its tongue. During the mentioned years the glacier tongue was raised by 240 meters above sea level and it was ended at a height of 1970 meters a.s.l. (Fig. 4b).

We had the last expedition to the glacier in 2011. Visual observation showed that the central flow of the glacier had a very weak contact with the two main flows. In the space image of 2012 this contact was already split. Therefore, we can conclude that their split took place exactly in 2012. As a result we got the northern Lekhziri (central flow) glacier the largest cirque glacier in Georgia and Lekhziri glacier (consists of two flows) - the largest compound-valley type glacier in Georgia.

The mentioned two main flows are covered by the weathered materials from the place of their junction to the end of their joint ice tongue. Evidently, the sharp surface ablation takes place in this section of the glacier as the ice is being diluted and weakened in many places. Contact between the two streams is expected to be interrupted in several years and two independent from each other glaciers will be formed[13].

Several medial moraines go along the ice tongue surface of the right and left flows, which means that the tongue is formed by joining of several glaciers. It should be noted that in the last section of the ice tongue of the Lekhziri glacier the medial moraines join each other and overlap the ice tongue by a powerful surface moraine, which makes difficult to separate the tongues of the individual flows. But $1 \mathrm{~km}$ above the ice tongue the individual flows are easily distinguishable by their morphographical signs and degree of surface pollution.

By the data of 2014 data the area of the Northen (Central) Lekhziri glacier is $6.3 \mathrm{~km}^{2}$. The area of the Lekhziri glacier consisted of two main flows is $23.3 \mathrm{~km}^{2}$. The ice tongue ends at a height of 2320 meters above sea level (Fig. 4c).

The eastern (left) flow of the Lekhziri glacier is formed by 
the five glaciers, after the merging which the icefall of $\sim 300$ meters in height is developed, further the ice tongue is characterized by a weak inclination. There are 5 medial moraine hillocks in its surface, which join each other in the last section of the tongue and is presented by the two powerful medial moraines. In general, the ice tongue is covered by the weathered materials.

There are a lot of different morpho-sculptural forms in the surface of the ice tongue, in particular, it should be noted the classic manifestation of ogives, which start from the icefall and after $\sim 1.0-1.5 \mathrm{~km}$ they gradually disappear. Their disappearance is caused by the weakening of the ice motion
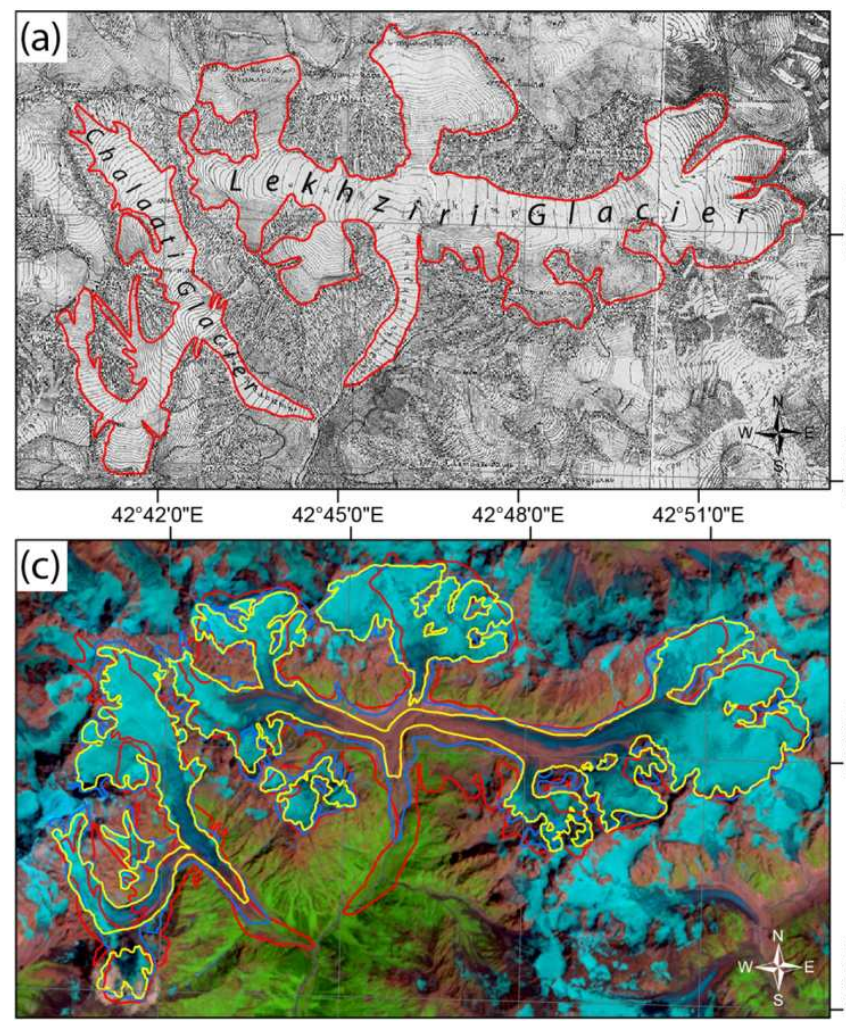

Fig. 4. The retreat of Lekhziri and Chalaati glaciersin 1911(a) - 1960(b) - 2014(c). The left main stream of the Chalaati glacier 1890(d) (Photo: V. sella) 2011(e) (Photo: L. Tielidze).

Chalaati glacier consists of two tributaries which are nourished by snowfall on a series of 4,000 m peaks: Ushba, Chatini, Cavcasi and Bzhedukhi [19]. The glacier terminus intrudes into the forest zone at an elevation of $1960 \mathrm{~m}$ a.s.1., making it the lowest-elevation terminus on the southern slopes of the Caucasus. The glacier has a total surface area of $8.6 \mathrm{~km}^{2}$ (Fig. 4e).

The eastern tributary forms the main channel of the glacier. It flows through three icefalls indicating the existence of ridges in the sub-glacial relief. The uppermost and largest icefall descends $\sim 300$ meters in height across a width of $\sim 700$ meters. The lower two icefalls are relatively small. In the vicinities of the icefalls the glacier tongue is divided (hillocks) by cracks of different directions. The lower reaches of the glacier are covered by debris $\sim 0.1-0.2$ meters thick. In the contact areas of the right and left streams and below, a middle moraine is being developed and the glacier is covered in the glacier in the last part of the ice tongue. There are a large number of glacial tables, wells, the "ant heaps", etc. Lateral moraines are developed to the right side of the before the icefall. Due to the affect of snow avalanches the moraines are not preserved below. However, on the slopes are well preserved traces of the glaciers of the Fernau stage.

The righthand western flow of the Lekhziri glacier is consisted of two icetongues, after their junction there are well expressed medial moraines on the surface of the glacier. Both of the ice tongues of the flow are covered by loose material in the last section.
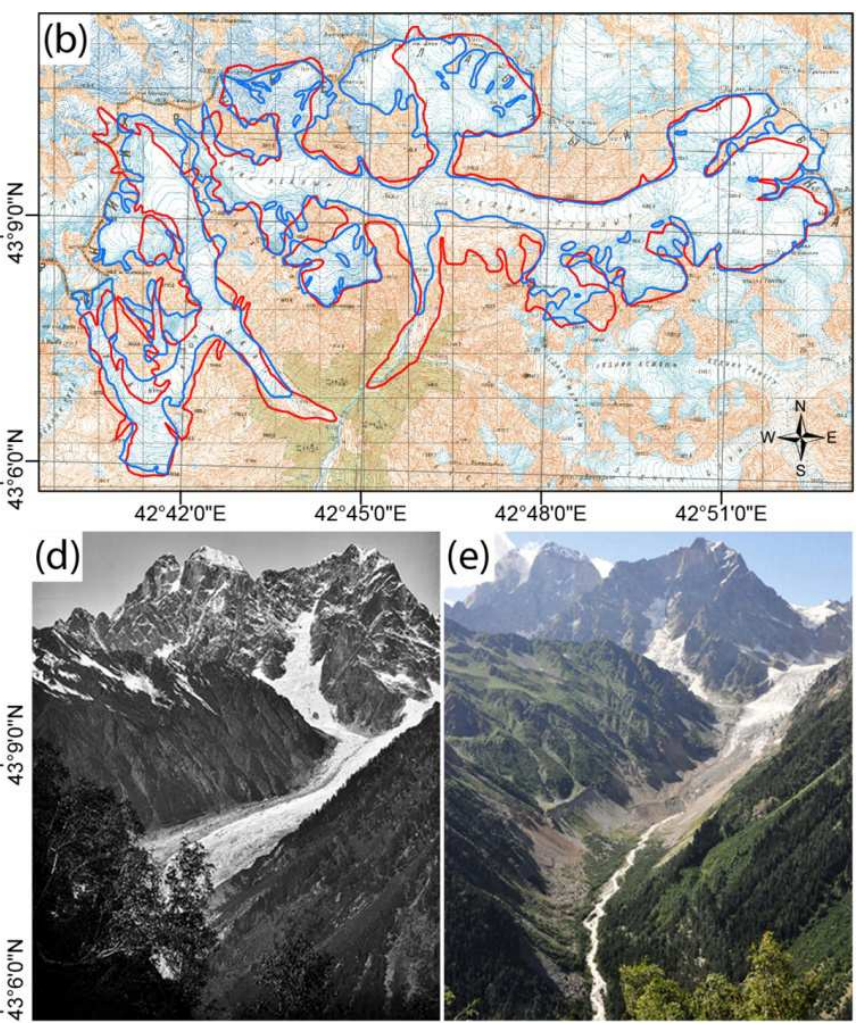

with a thick layer of weathered material. These streams will be divided in the near future [13].

Glacier surface is characterized by powerful quakes. At this time the small fountains are formed in the surface of the glacier. Ice movement within the Glacier is great, especially during the quakes. The middle part of the glacier tongue is very inclined and cracked. Glacier tongue morphology is determined by the thickness of the accumulated on it loose material. Clastic material in the glacier surface increases its melting velocity. Below the Chalaati tongue the frontal moraines can be observed in certain distance away, which are located wide in the gorge as a form of hillocks. The layout of frontal moraine indicates the glacier movement, while the each line of frontal moraine - in its brief stop.

Chalaati glacier reached its most recent maximum position during the Little Ice Age which, in the Caucasus lasted from the 1650-1850. In 1810, the glacier tongue extended down to 
1620 meters, as evidenced by the recent stage moraines and erratic boulders in the pro-glacial valley. At this time, the glacier area was $15.1 \mathrm{~km}^{2}$ [13] (Table 1).

Table 1. Morphometric parameters of the Chalaati glacier in 1810-2014.

\begin{tabular}{lll}
\hline Years & Tongue height above sea level, $\mathbf{m}$ & Area, $\mathbf{k m}^{\mathbf{2}}$ \\
\hline 1810 & 1620 & 15.1 \\
1910 & 1650 & 12.2 \\
1960 & 1800 & 12.8 \\
1986 & 1890 & 11.6 \\
2000 & 1930 & 9.4 \\
2014 & 1960 & 8.6 \\
\hline
\end{tabular}

According to the data of 1911 the Chalaati glacier area was $12.2 \mathrm{~km}^{2}$ and its tongue ended at a height of 1650 meters (Fig. $4 \mathrm{a})$. In the topographic map of 1960 the glacier area is by 0.6 $\mathrm{km}^{2}$ more than in 1911. If we trust the mentioned data, it means that in this period the glacier area was increased, but if we look at the dynamics of the glacier tongue, we will see that its tongue is shorter by about $1.1 \mathrm{~km}$ and is elevated by
150 meters (Fig. 4b).

The glacier area increase in the years of 1911-1960 is not true and this defect is caused by the incorrect depiction of the Chalaati firn contour in the old topographic map; particularly, almost $1 / 3$ of the firn of the left main flow of the glacier is not depicted in the map at all.

According to the data of 2014 the Chalaati glacier area is $8.6 \mathrm{~km}^{2}$ and the glacier tongue ends at a height of $1960 \mathrm{~m}$ above sea level (Fig. 4c).

\section{Discussion}

In addition to the old topographic maps and modern space images it is important to take into account the climatic conditions during the study of the glacier dynamics. For this purpose we use the air temperature data of Mestia meteorological station from 1906 to 2013 inclusive (Fig. 5). Mestia meteorological station is located $7 \mathrm{~km}$ down the valley from the Chalaati terminus at an elevation of $1441 \mathrm{~m}$.

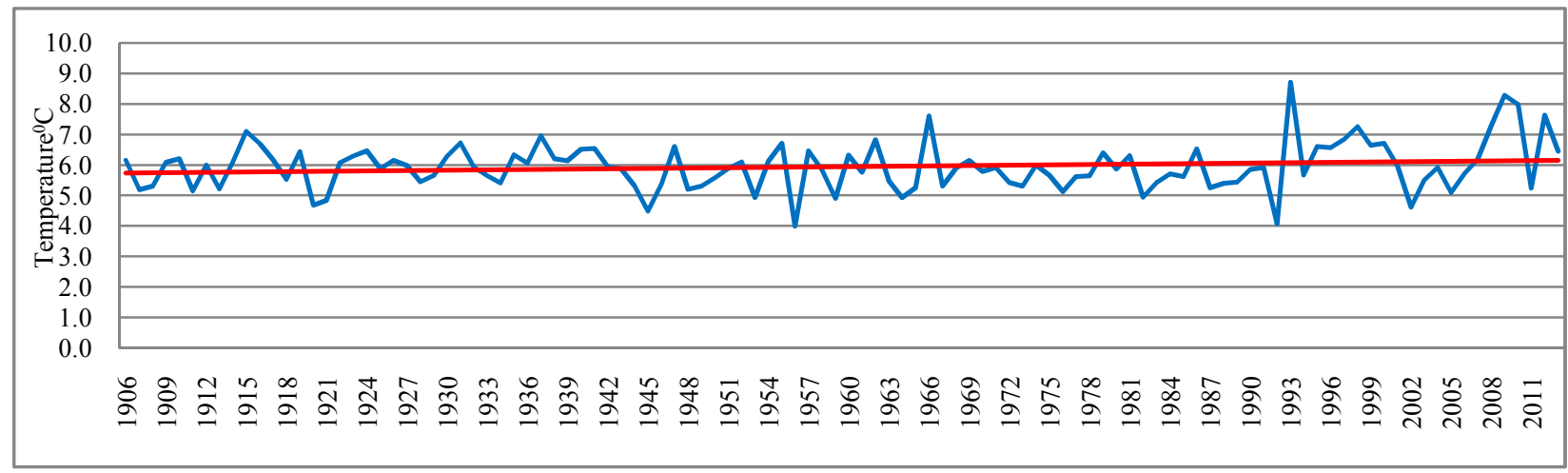

Fig. 5. The course of the mean air temperatures at the Mestia weather station in 1906-2013.

The figure shows the temperature trend is positive. We should particularly highlight the last 30-year period (19842013), when the mean multiannual air temperature is higher by $+0.3^{\circ} \mathrm{C}$ than the mean secular temperature $\left(+5.9^{\circ} \mathrm{C}\right)$ and it makes $+6.2^{\circ} \mathrm{C}$. Accordingly, the reduction of the glaciers in the area in parallel with the air temperature increase during the last one century fits the logical frame.

It will be interesting to compare the Mestia weather station air temperature data with the same data of the Chalaati glacier weather station and link it to the Chalaati ablation. As we mentioned above, in the summer season of 2011 we were conducting the stationary observation on the Chalaati glacier.

We determined altitudinal temperature gradient between in our air temperature data obtained (2011), and air temperature of Mestia weather station at the same period. Correlation was made between them. Thantemperature data so the average annual of glacier Chalaati during the period 1906-2013 were restored with equation derived from transfer function (Fig.6). So, the average annual air temperature of glacier Chalaati during the period 1906-2013 were restored with equation derived from transfer function (Fig. 6).

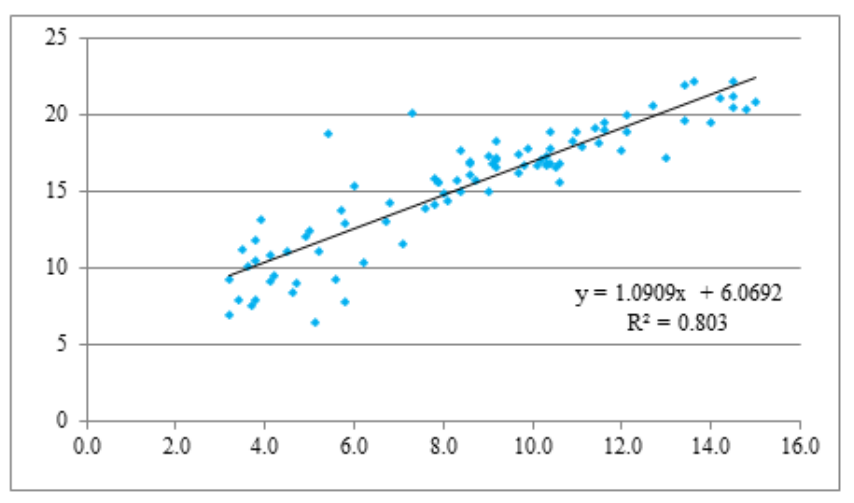

Fig. 6. Linear correlation received through transfer function. 
The overlapping summer 2011 observations at Mestia and Chalaati Glacier enable us to compute the adiabatic lapse rate (temperature gradient) for the region, and also establish a transfer function that we can use to extend the Chalaati record back to 1906 . The derived lapse rate is $-9.8^{\circ} \mathrm{C} / \mathrm{km}$. For the transfer function, we need to confirm that temperatures at both sites are well correlated. A linear correlation between Mestia and Chalaati yields a correlation coefficient of 0.8 , showing a significant correlation between both records. On that basis, we apply the linear coefficients to the Mestia time series to reconstruct a 107-year long temperature time series for Chalaati Glacier (Fig.7).

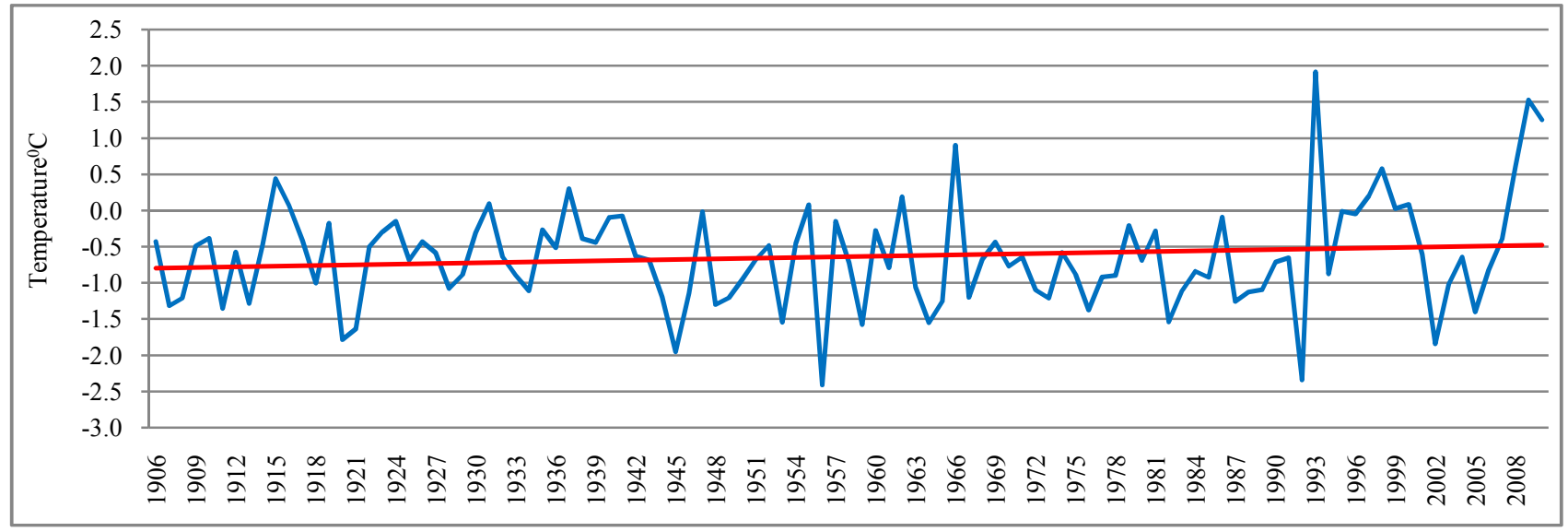

Fig. 7. The course of the mean air temperatures at the Chalaati weather station (2140 m. a.s.l.) in 1906-2013.

Figure shows that in the glacier the temperature trend is positive. Especially noteworthy is the year of 1993, when during the last century the highest mean annual temperature $+1.9^{\circ} \mathrm{C}$ is observed. In the last 30 years the mean multiannual temperature like in Mestia, is higher by $0.3^{\circ} \mathrm{C}$ than the mean secular temperature and makes $-0.4^{\circ} \mathrm{C}$.

Observations made in the field in summer 2011 allow us to examine the role of air temperature on ablation. Ablation was recorded as changes in exposed heights of stakes emplaced at several locations on the glacier surface. By using the Chalaati temperature observations and the derived lapse rate from Mestia to Chalaati, we can produce a 'local' temperature record for each stake location. To facilitate comparison with the ablation records, we compute the cumulative positive degree days for each stake location [20]. Results are shown in Figure 8.

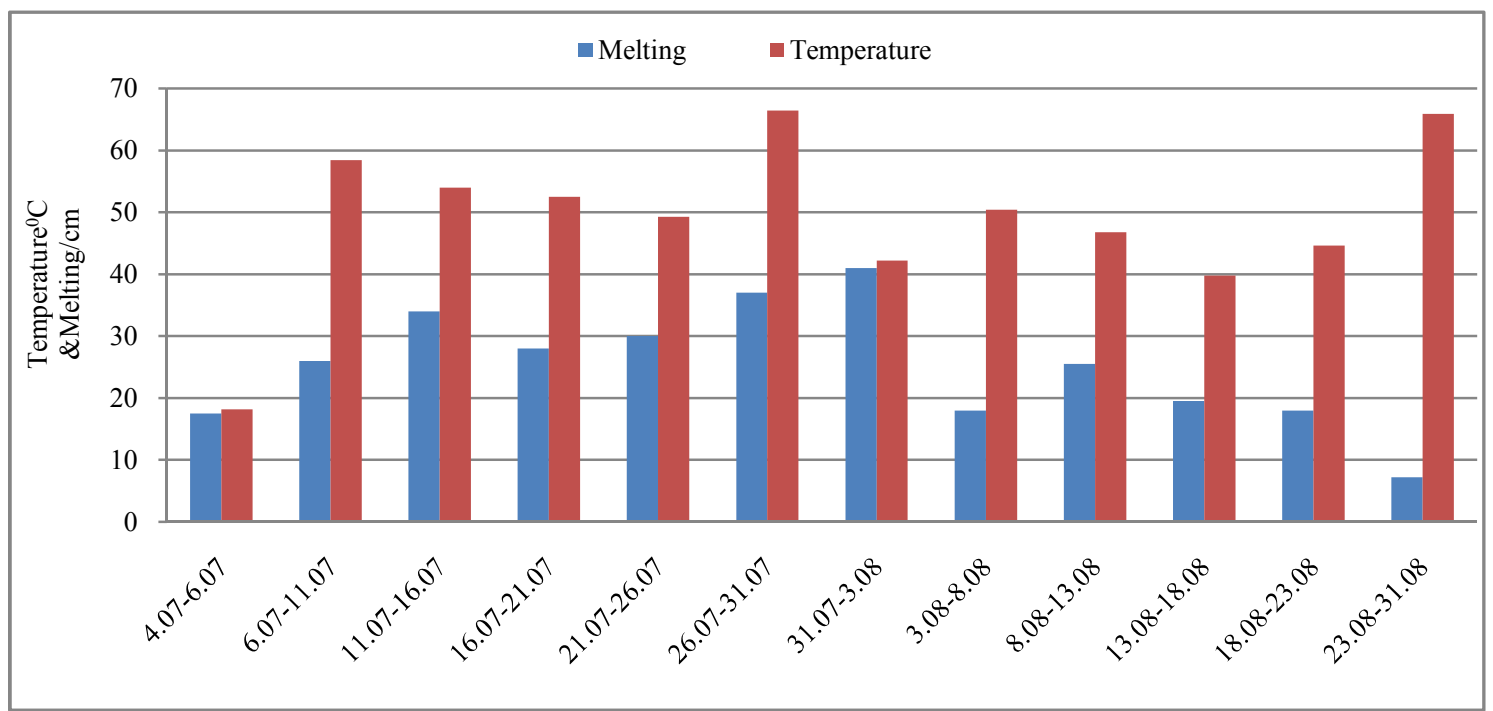

Fig. 8. Diagram of dependence between air temperature sum and ice cover melt sum on Chalaati glacier surface at the same height From 4 July to 31 August (2040 m. a.s.l).

Graph shows that sum of air temperatures and sum of ice melt in July exceeds indicators for August. Specifically, the temperature sum is $298.8^{\circ} \mathrm{C}$ and ice melt data is and $172.5 \mathrm{~cm}$ for 27 days from July 4 to July 31. But in August the temperature sum is $289.7^{\circ} \mathrm{C}$ and ice melt is $129.0 \mathrm{~cm}$ for 31 days from July 31 until August 31. This again establishes that
July is characterized by a higher temperature and ice melt than in August. A partial explanation for higher melt values in July is solar angle, which in July is farther above the horizon than in August and thus supplies greater amounts of incoming radiation to melt the glacier surface. 


\section{Conclusions}

As a result of the research we concluded that the area of glaciers in the Mestiachala River basin was reduced by $20.1 \%$ in 1911-2014 while their number was decreased by $52.4 \%$ (Fig. 9). Increase in the area of the glaciers in 1911-1960 is not true, because the firns of the Lekhziri and Chalaati glaciers were depicted in the old topographic maps with the smaller area than it actually was. And the correct depiction of the contours of the firn basins mentioned in the maps of 1960 caused the increase of the glaciers in area. As for the years of $1960-2014$, the area of the glaciers was decreased by $23.30 \%$ and their number - by $16 \%$ (Fig 9).

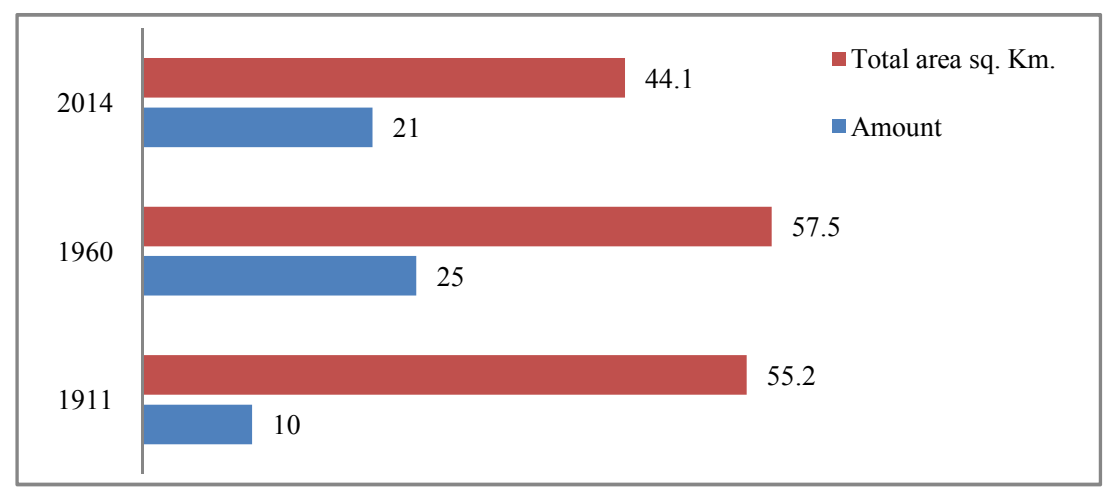

Fig. 9. Changes in the number and area of the Chalaati River basin glaciers in 1911-1960-2014.

The Lekhziri glacier area was reduced by $35.3 \%$ in the last century. The greatest reduction in the Lekhziri area was observed in 2012 when the central flow was separated from it and was formed as a separate cirque type of glacier. In the mentioned period the Lekhziri tongue was retreated by about 3.5 kilometers.

In case of Chalaati glacier, the maximum reduction is observed in the years of 1986-2000 when the two small glaciers were separated from its right flow. In total, the area of the glacier was reduced by $30.0 \%$ in $1911-2014$. The glacier tongue retreated by about 1.8 kilometers.

As we mentioned above, the existence of glaciers in the Caucasus, along with relief is determined by the climatic conditions. In particular, atmospheric precipitation and air temperature. This part of the Enguri River upper stream basin is bordered by the main watershed range from the north and by the Svaneti range from the south. In addition, shifting of the humid air masses coming from the Black Sea, are prevented by a high Egrisi range. As a result, the area of Zemo Svaneti is characterized by a relatively small humidity.

It's to be mentioned that due to such location Mestia cavernous and Mestiachala River gorge of solid precipitation aren't distinguished with great abundance (compare to the south slope of the Caucasus of Abkhazeti), especially in the last years as mentioned above for 2011-2012 winter is the least snowy during the last 54 years. Therefore, it's likely to be one of the factor for the increased pace of glacier reduction.

\section{Acknowledgements}

We are grateful to the Shota Rustaveli Georgian National Science Foundation for the financing our research. We would like to express our heartfelt thanks to the Hydro Meteorological Department of the National Agency of the Environment for providing the meteorological data.

\section{References}

[1] Gregory J. M., White, N. J., Church, J. A., Bierkens, M. F. P., Box, J. E., van den Broeke, M. R., Cogley, J. G., Fettweis, X., Hanna, E., Huybrechts, P., Konikow, L. F., Leclercq, P. W., Marzeion, B., Oerlemans, J., Tamisiea, M. E., Wada, Y., Wake, L. M., and van de Wal, R. S. W.: Twentieth-century globalmean sea-level rise: is the whole greater than the sum of the parts?, J.Climate, 26, 4476-4499, doi: 10.1175/JCLI-D-1200319.1, 2013.

[2] Zemp M., Haeberli W., (2014) Glaciers and Ice caps. p.116.

[3] Leclercq P. W., Oerlemans J., Basagic H. J., Bushueva I., Cook A. J. and Le Bris R. A data set of worldwide glacier length fluctuations. The Cryosphere, 8, 659-672, 2014.

[4] Carrivick J. L., and Chase S. E., (2011) Spatial and temporal variability of annual glacier equilibrium line altitudes in the Southern Alps, New Zealand. New Zeal. J. Geol. Geophys., 54(4), 415-429 (doi: 10.1080/00288306.2011.607463)

[5] Radic V. and Hock R. (2011) Regionally differentiated contribution of mountain glaciers and ice caps to future sealevel rise. Natur.Geosci., 4(2), 91-94 (doi: 10.1038/ngeo1052)

[6] Marzeion B., Jarosch A.H. and Hofer M. (2012) Past and future sealevel change from the surface mass balance of glaciers. Cryosphere, 6(6), 1295-1322 (doi: 10.5194/tc-61295-2012)

[7] Slangen A. B. A., Katsman C. A., Van de Wal R. S. W., Vermeersen LLA and Riva REM (2012) Towards regional projections of twenty-first century sea-level change based on IPCC SRES scenarios. Climate Dyn., 38(5-6), 1191-1209 (doi: 10.1007/s00382-011-1057-6)

[8] Radic V., Bliss A., Beedlow A. C., Hock R., Miles and Cogley J. G., (2014) Regional and global projection of twenty-first century glacier mass change in response to climate scenarios from global climate models. Climate Dyn. 42 (1-2), 37-58 (doi: 10.1007/s00382-013-1719-7) 
[9] Oerlemans J. and J. P. F. Fortuin. 1992. Sensitivity of glaciers andsmall ice caps to greenhouse warming. Science, 258(5079),115-117.

[10] Haeberli W., M. Maisch and F. Paul. 2002. Mountain glaciers inglobal climate-related observation networks. WMO Bull., 51(1), 18-25.

[11] Solomon S. and 7 others, eds. 2007. Climate change 2007: the physical science basis. Contribution of Working Group I to the Fourth Assessment Report of the Intergovernmental Panel on Climate Change. Cambridge, etc., Cambridge University Press

[12] Dyurgerov M. (2003), Mountain and sub-polar glaciers show an increase in sensitivity to climatic warming and intensification of the water cycle, J. Hydrol., 282, 164-176.

[13] Tielidze L. G. 2014. Glaciers of Georgia, Monograph. Publ. „Color” 254 p. ISBN 978-9941-0-6809-6 (in Georgian).

[14] Kotlyakov V. M., Dyakova A. M., Koryakin V. S., Kravtsova V. I., Osipova G. B., Varnakova G. M., Vinogradov V. N., Vinogradov O. N. and Zverkova N. M. (2010) Glaciers of the former Soviet Union. In: Williams, R. S. Jnr and Ferrigno, J.G., (eds.) Satellite image atlas of glaciers of the world Glaciers of Asia: U.S. Geological Survey Professional Paper 1386-F-4 (doi:1386-F-4)
[15] Kordzakhia R. 1967. Enguri and Tskhenistskhali river basins climate features within the Svaneti. Acts of Georgian Geographical Society. Vol. IX-X. p. 110-125. (in Georgian).

[16] Podozerskiy K. I. (1911). Glaciers of the Caucasus Mountain Range. "Zap. KORGO”, vol. 14, issue 1, (in Russian ).

[17] Gobejishvili R. G. 1989. Glaciers of Georgia. Monograph. Publ. "Metsniereba". (In Russian).

[18] Raup B., A. Kaeaeb, J. Kargel, M.P. Bishop, G.S. Hamilton, E. Lee, F. Rau, F. Paul, D. Soltesz, S.J. Singh Kalsa, M. Beedle \& C. Helm. 2007. Remote Sensing and GIS technology in the Global Land Ice Measurements from Space (GLIMS) Project. Computers and Geoscience, 33, 104-125.

[19] Gobejishvili R. G., Tielidze L. G., Lomidze N. N, Javakhishvili A. 2012. Monitoring of Glaciers on the background of Climate change. Monograph, Publ. "Universali" 176 p. (in Georgian).

[20] Hock R., 1999. A distributed temperature-index ice and snowmelt model including potential direct solar radiation, Journal of Glaciology, 45(149), 101-111. 